\title{
Model Pengembangan Rasio Solvabilitas Untuk Meningkatkan Pertumbuhan Laba Dimediasi Oleh Profitabilitas (Studi Kasus Pada Perusahaan LQ-45 di BEI)
}

\author{
Hendry Saladin ${ }^{1}$, Benny Usman ${ }^{2}$ \\ ${ }^{1}$ Jurusan Akuntansi Fakultas Ekonomi Univ.PGRI Palembang, Email: hendrysaladin43@gmail.com \\ 2Jurusan Manajemen Fakultas Ekonomi Univ. PGRI Palembang, Email: broperlengkapan@gmail.com
}

\begin{abstract}
ABSTRAK
Tujuan penelitian ini adalah untuk mengetahui Debt to Assets Ratio (DAR) dan Debt to Equity Ratio (DER) terhadap pertumbuhan laba yang dimediasi oleh Return on Assets (ROA) pada perusahan LQ45 yang terdaftar di Bursa Efek Indonesia periode 2014-2017 dan sekaligus membantu perusahaan yang tergabung dalam LQ-45 untuk menemukan sekaligus memecahkan permasalahan untuk meningkatkan pertumbahan laba melalui rasio keuangan terutama rasio solvabilitas dan rasio profitabilitas. Untuk jangka panjang penulis ingin capai adalah agar perusahaan yang terindek di LQ45 yang terdaftar di Bursa Efek Indonesia dengan menggunakan rasio keuangan terutama rasio solvabilitas dan profitabilitas dapat meningkatkan pertumbuhan laba di masa mendatang. Target khusus yang ingin dicapai adalah sebagai masukan dan pertimbangan bagi perusahaan LQ- 45 dalam memprediksi pertumbuhan laba pada masa yang akan datang. Model analisis yang digunakan adalah analisis jalur (Path Analysis). Metode analisis ini bertujuan mengetahui pengaruh langsung dan tidak langsung maupun variabel total beberapa variabel penyebab (eksogen) terhadap variabel endogen (akibat) dengan pola hubungan antar variabel adalah satu arah dan semua variabel dapat diobservasi langsung. Hasil penelitian menunjukkan bahwa Debt to Assets Ratio secara langsung berpengaruh positif dan tidak signifikan terhadap Return On Assets dengan koefisien path sebesar 0,319, Debt to Equity Ratio secara langsung berpengaruh negatif dan signifikan terhadap Return On Assets dengan koefisien path sebesar -0,647, Debt to Assets Ratio secara langsung berpengaruh positif dan signifikan terhadap pertumbuhan laba dengan koefisien path sebesar 0,549, Debt to Equity Ratio secara langsung berpengaruh negatif dan signifikan terhadap pertumbuhan laba dengan koefisien path sebesar -0,670, Return On Assets secara langsung berpengaruh negatif dan signifikan terhadap pertumbuhan laba dengan koefisien path sebesar -0,423, ROA bukan merupakan variabel intervening atau mediating dari DAR terhadap pertumbuhan laba, ROA merupakan variabel intervening atau mediating dari DER terhadap pertumbuhan laba, secara simultan ROA merupakan variabel intervening atau mediating dari DAR dan DER terhadap pertumbuhan laba pada Perusahaan LQ-45 yang terdaftar di BEI periode $2014-2017$.
\end{abstract}

Kata kunci : $D A R, D E R, R O A$ dan Pertumbuhan Laba

\section{A. LATAR BELAKANG}

Tujuan perusahaan pada umumnya adalah memperoleh laba. Akan tetapi laba yang besar belum tentu memaksimalkan nilai perusahaan. Kemampuan menghasilkan laba yang maksimal pada suatu perusahaan sangat penting karena pada dasarnya pihak-pihak yang berkepentingan, misalnya investor dan kreditor mengukur keberhasilan perusahaan berdasarkan kemampuan perusahaan yang terlihat dari kinerja manajemen dalam menghasilkan laba dimasa mendatang (Suprihatmi, 2005).

Dari sudut pandang investor, salah satu indikator penting untuk menilai prospek perusahaan di masa datang adalah dengan melihat sejauhmana pertumbuhan solvabilitas dalam mengukur seberapa besar penggunaan utang dalam pembelanjaan perusahaan dan profitabilitas sebagai variabel mediasi merupakan rasio yang menunjukkan ukuran tingkat efektivitas manajemen suatu perusahaan yang ditunjukkan 
dari laba yang dihasilkan dari penjualan atau dari pendapatan investasi.

Beberapa penelitian yang telah dilakukan untuk menguji kemampuan rasio keuangan untuk memprediksi laba, diantaranya adalah penelitian yang berkaitan dengan solvabilitas terhadap pertumbuhan laba dilakukan oleh (Ifada, Luluk Muhimatul \& Tiara Puspitasari, 2016; Wibisono, Septian Adi \& Triyonowati, 2016; Zakaria, Mohamad Rizki. Dkk, 2015; Oktanto, Danny \& Muhammad Nuryatno Amin, 2014; Hermanto, Suwardi B., 2007) hasil pengujian menunjukkan bahwa DAR mempunyai pengaruh signifikan terhadap pertumbuhan laba. Namun penelitian lain menunjukan hasil yang berbeda (Nunki, Kadek \& Sasi Agustin, 2014; Kurniawati, Yesi Astuti \& Triyonowati, 2017). Dengan hasil ini menunjukkan bahwa perusahaan tidak mampu menutupi seluruh beban bunga yang harus dibayar karena dana hutang yang digunakan perusahaan terlampau tinggi, maka akan mengakibatkan penurunan laba yang diperoleh perusahaan.

Selain DAR rasio keuangan yang menentukan laba adalah DER (Mahaputra, I Nyoman Kusuma Adnyana, 2012; Hermanto, Suwardi B., 2007; Oktanto, Danny \& Muhammad Nuryatno Amin, 2014; Wibisono, Septian Adi \& Triyonowati, 2016; Narpatilova, Oktapiana, 2013) yang menyatakan bahwa proporsi Debt to Equity Ratio (DER) berpengaruh signifikan terhadap Pertumbuhan Laba. Namun penelitian ini tidak sejalan dengan penelitian yang dilakukan oleh (Ifada, Luluk Muhimatul \& Tiara Puspitasari, 2016; Meilyanti, 2017; Lestari, Sri, 2014) hasil pengujian menunjukkan bahwa DER tidak mempunyai pengaruh dengan perubahan laba perusahaan.
Faktor lain yang mempengaruhi pertumbuhan laba adalah ROA (Susanti. Nita Hari \& Siti Rokhmi Fuadati, 2014; Sulistyowati \& Bambang Suryono, 2017; Meilyanti, 2017; Martunis \& Ghazali Syamni, 2013; Prasetyo, Rony Yuda. Dkk,. 2016) yang menunjukkan $R O A$ berpengaruh signifikan terhadap perubahan laba perusahaan. Hal ini sejalan dengan teori yang menyatakan bahwa semakin tingginya rasio $R O A$ menunjukkan bahwa semakin besar kemampuan perusahaan mengelola aktiva yang dimiliki secara efektif dan efisien, sehingga dapat mendukung pertumbuhan laba (Meilyanti, 2017). Tetapi penelitian ini tidak konsisten dengan penelitian yang dilakukan oleh (Riana D, Diyani LA, 2016; yang menghasilkan bahwa ROA tidak berpengaruh dalam memprediksi perubahan laba.

Permasalahan dalam penelitian ini adalah apakah ada pengaruh DAR dan DER terhadap pertumbuhan laba yang dimediasi oleh ROA pada perusahan LQ-45 yang terdaftar di $\mathrm{BEI}$. Sedangkan tujuan dari penelitian ini untuk mengetahui dan mengkaji DAR dan DER terhadap pertumbuhan laba yang dimediasi oleh ROA pada perusahan LQ-45 yang terdaftar di BEl.

Dalam penelitian ini penulis akan mengkaji ulang model pengembangan rasio solvabilitas untuk meningkatkan pertumbuhan laba yang dimediasi oleh profitabilitas pada perusahaan LQ-45 di BEl, sehingga apa yang menjadi hasil penelitian nantinya akan mempertegas dan memperkuat teori yang ada.

\section{B. TINJAUAN PUSTAKA Rasio Solvabilitas}

Menurut Kasmir (2010), Solvabilitas merupakan rasio yang digunakan untuk mengukur sajauh 
mana aktiva perusahaan dibiayai dengan utang. Artinya berapa besar beban utang yang ditanggung perusahaan dibandingkan dengan aktivanya. Dalam arti luas dikatakan bahwa rasio solvabilitas digunakan untuk mengukur kamampuan perusahaan untuk membayar seluruh kewajibanya, baik jangka pendek maupun jangka penjang apabila perusahaan dibubarkan.

Sedangkan Sartono (2010), mendefinisikan Rasio leverage (solvabilitas) menunjukan kapasitas perusahaan untuk memenuhi kewajiban baik itu jangka pendek maupun jangka panjang. Rasio leverage terdiri dari Debt Ratio, Debt to Equity Ratio, Time interest earned ratio, Fixed charge coverage dan Debt Service Coverage.

Menurut Sudana (2011), Rasio solvabilitas, adalah rasio yang menunjukkan kemampuan perusahaan dalam membayar kewajiban jangka panjangnya atau kewajibankewajibannya apabila perusahaan dilikuidasi. Kasmir (2014) mendefinisikan bahwa Rasio Solvabilitas atau Leverage Ratio merupakan rasio yang digunakan untuk mengukur sejauh mana aktiva perusahaan dibiayai dengan utang, artinya berapa besar beban utang yang ditanggung perusahaan dibandingkan dengan aktivanya.

Berdasarkan beberapa definisi diatas, maka dapat disimpulkan bahwa rasio solvabilitas adalah rasio untuk menilai kemampuan perusahaan untuk membayar seluruh kewajibannya, baik jangka pendek maupun jangka panjang apabila perusahaan dibubarkan. Semakin tinggi solvabilitas, perusahaan harus semaksimal mungkin meningkatkan labanya agar mampu membiayai dan membayar utang. Solvabilitas yang tinggi menjadi perhatian auditor karena solvabilitas yang tinggi mengidentifikasikan bahwa perusahaan tidak dapat mempertahankan kelangsungan hidupnya (Petronela, 2004).

Solvabilitas dalam penelitian ini diukur dengan Debt to Assets Ratio (DAR) dan Debt to equity Ratio (DER).

\section{Debt to Assets Ratio (DAR)}

Debt Ratio merupakan rasio utang yang digunakan untuk mengukur perbandingan antara total utang dengan total aktiva. Dengan kata lain, seberapa besar aktiva perusahaan dibiayai oleh utang atau seberapa besar utang perusahaan berpengaruh terhadap pengelolaan aktiva (Kasmir, 2014). Semakin rendah debt ratio maka akan meningkatkan laba sehingga semakin besar jaminan kreditor untuk pengembalian atas pinjaman yang diberikan oleh pihak perusahaan (Fahmi, 2012).

Menurut Raharjaputra (2009) Debt ratio adalah salah satu rasio leverage. Rasio ini digunakan untuk mengukur jumlah persentase dari jumlah dana yang diberikan oleh kreditur berupa utang terhadap jumlah aset perusahaan.

Dari hasil pengukuran, apabila rasionya tinggi, artinya pendanaan dengan utang semakin banyak maka semakin sulit bagi perusahaan untuk memperoleh tambahan pinjaman karena dikhawatirkan perusahaan tidak mampu menutupi utang-utangnya dengan aktiva yang dimilikinya. Demikian pula apabila rasionya rendah, semakin kecil perusahaan dibiayai dengan utang.

\section{Debt to Equity Ratio (DER)}

Debt to Equity Ratio merupakan rasio yang digunakan untuk mengukur perbandingan antara total modal dengan total aktiva (Kasmir, 2014). Rasio utang (debt to equity ratio) 
menunjukan beberapa banyak utang yang digunakan membiayai aset-aset perusahaan. Sedangkan Rasio DER menurut Andarini (2007) dipergunakan untuk mengukur tingkat penggunaan utang terhadap total shareholder's equity yang dimiliki perusahaan. Dengan kata lain, seberapa besar aktiva perusahaan dibiayai oleh utang atau seberapa besar utang perusahaan berpengaruh terhadap pengelolaan aktiva.

Apabila rasionya tinggi, artinya pendanaan dengan utang semakin banyak, maka semakin sulit bagi perusahaan untuk memperoleh tambahan pinjaman karena dikhawatirkan perusahaan tidak mempu menutupi utang-utangnya dengan aktiva yang dimilikinya. Demikian pula sebaliknya, apabila rasio rendah, semakin kecil perusahaan dibiayai oleh utang (Kasmir, 2014). Standar pengukuran untuk menilai baik tidaknya rasio perusahaan, digunakan rasio rata-rata industri sejenis.

Menurut Cahyaningrum dan Mulyo (2011), DER yang tinggi menunjukkan tingginya tingkat penggunaan hutang sebagai sumber pendanaan oleh perusahaan. Ini akan menimbulkan risiko yang cukup besar ketika perusahaan tidak mampu membayar kewajibannya ketika jatuh tempo. Kewajiban yang tidak dapat terpenuhi ketika jatuh tempo akan menimbulkan beban bunga yang tinggi sehingga akan menurunkan perolehan laba bagi perusahaan.

\section{Rasio Profitabilitas}

Menurut Sartono (2010), yang menyatakan bahwa : profitabilitas adalah kemampuan perusahaan memperoleh laba dalam hubungannya dengan penjualan, total aktiva maupun modal sendiri.
Rasio profitabilitas sering juga disebut sebagai rasio rentabilitas, menurut Moeljadi (2008) rasio profitabilitas adalah rasio yang berusaha mengukur kemampuan perusahaan untuk menghasilkan laba, baik dengan menggunakan seluruh aktiva yang ada maupun dengan menggunakan modal sendiri.

Sementara itu rasio profitabilitas menurut Harahap (2011) adalah yang menggambarkan kemampuan perusahaan mendapatkan laba melalui semua kemampuan, dan sumber yang ada seperti kegiatan penjualan, kas, modal, jumlah karyawan, jumlah cabang, dan sebagainya. Sedangkan menurut Kasmir (2014) rasio profitabilitas merupakan rasio untuk menilai kemampuan perusahaan dalam mencari keuntungan. Rasio ini juga memberikan ukuran tingkat efektivitas manajemen suatu perusahaan. Hal ini ditunjukan oleh laba yang dihasilkan dari penjualan dan pendapatan investasi. Intinya adalah penggunaan rasio ini menunjukkan efisiensi perusahaan.

Berdasarkan pendapat para ahli di atas, dapat ditarik kesimpulan bahwa rasio profitabilitas adalah rasio untuk mengukur tingkat efektifitas pengelolaan (manajemen) perusahaan yang ditunjukkan oleh jumlah keuntungan yang dihasilkan dari penjualan dan investasi. Intinya adalah penggunaan rasio ini menunjukkan efisiensi perusahaan.

Profitabilitas dalam penelitian ini diukur dengan Retutn on Asset (ROA). Return on assets (ROA) merupakan rasio yang menunjukan hasil (return) atas jumlah aktiva yang digunakan dalam perusahaan atas suatu ukuran tentang aktivitas manajemen (Kasmir, 2014).

Semakin besar Retutn on Asset (ROA) suatu perusahaan, maka semakin baik pula posisi perusahaan 
tersebut dari segi penggunaaan aset. Dengan pencapaian laba yang tinggi, maka investor dapat mengharapkan tingkat pengembalian yang tinggi, maka apabila suatu saham menghasilkan tingkat pengembalian yang tinggi tersebut maka berdampak pada peningkatan harga saham.

\section{Pertumbuhan Laba}

Menurut Rusmanto (2011), pertumbuhan laba merupakan ukuran kinerja dari suatu perusahaan untuk menghitung laba dimasa yang akan datang dengan menggunakan laba diperiode sebelumnya. Pertumbuhan laba adalah perubahan dari persentase kenaikan laba perusahaan yang diperoleh oleh perusahaan selama satu periode tertentu (Taruh : 2011). Sedangkan Prihartanty (2011), pertumbuhan laba merupakan salah satu rasio pertumbuhan yang digunakan untuk mengukur kinerja perusahaan.

Fahmi (2012), rasio pertumbuhan adalah rasio yang digunakan untuk mengukur kemampuan perusahaan dalam mempertahankan posisinya didalam industry dan perkembangan ekonomi secara umum.

Pertumbuhan laba dipengaruhi oleh perubahan komponen-komponen dalam laporan keuangan. Pertumbuhan laba yang disebabkan oleh perubahan komponen laporan keuangan misalnya perubahan penjualan, perubahan harga pokok penjualan, perubahan beban operasi, perubahan beban bunga, perubahan pajak penghasilan, adanya perubahan pada pos-pos luar biasa, dan lain-lain. Perubahan laba dapat juga disebabkan oleh faktor-faktor luar seperti adanya peningkatan harga akibat inflasi dan adanya kebebasan manajerial yang memungkinkan manajer memilih metode akuntansi dan membuat estimasi yang dapat meningkatkan laba.

\section{METODE PENELITIAN Rancangan Penelitian}

Penelitian ini termasuk dalam kategori penelitian kuantitatif. Pendekatan kuantitatif merupakan metode pemecahan masalah yang terencana dan cermat, dengan desain yang terstruktur ketat, pengumpulan data secara sistematis terkontrol dan tertuju pada penyusunan teori yang disimpulkan secara induktif dalam kerangka pembuktian hipotesis secara empiris.

Penelitian ini menguji pengaruh variabel bebas terhadap variabel terikat. Penelitian kuantitatif merupakan paradigma penelitian yang menggunakan pendekatan deduktif. Pendekatan deduktif bertujuan untuk menguji hipotesis melalui validasi teori atau pengujian aplikasi teori pada keadaan tertentu (Indriantoro dan Supomo, 2013).

\section{POPULASI DAN SAMPEL}

Populasi dalam penelitian ini adalah adalah seluruh perusahaan LQ45 yang tedaftar di Bursa Efek Indonesia sebanyak 45 Perusahaan periode $2014-2017$. Teknik sampling yang digunakan oleh penulis adalah teknik purposive sampling. Dengan kriteria yang digunakan penulis dalam proses pengambilan sampel adalah sebagai berikut :

a. Perusahaan yang diteliti adalah seluruh perusahaan indeks LQ-45 yang terdaftar di Bursa Efek Indonesia pada tahun 2014 - 2017.

b. Perusahaan yang diteliti adalah perusahaan

mempublikasikan

yang

keuangan periode

laporan

yang sudah diaudit. 
c. Perusahaan yang diteliti harus memiliki laba selama periode penelitian.

\section{E. MODEL PENELITIAN}

Pada penelitian ini menggunakan model Analisis Jalur (Path Analysis). Menurut Webley sebagaimana dikutip Pardede (2014) analisis jalur merupakan pengembangan langsung bentuk regresi berganda dengan tujuan untuk memberikan estimasi tingkat kepentingan (magnitude) dan signifikansi (significance) hubungan sebab akibat hipotetikal dalam seperangkat variabel.

Untuk kepentingan penelitian dalam menghitung pengaruh antar variabel, variabel DAR disimbulkan dengan $X_{1}, D E R$ dengan $X_{2}, R O A$ dengan $Z$ dan pertumbuhan laba dengan Y. Model konstelasi antar variabel penelitian ini digambarkan sebagai berikut :

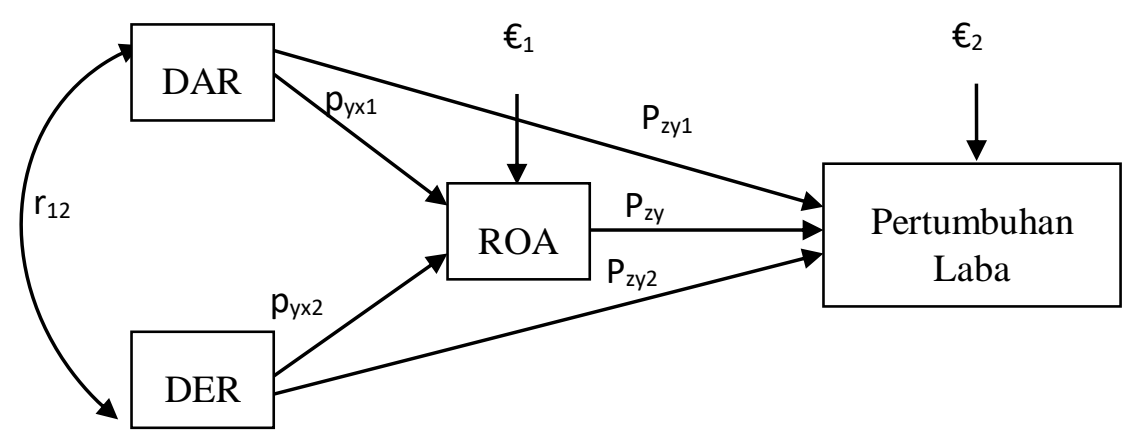

Gambar 1. Model Diagram Jalur (Path Analysis)

\section{Uji Asumsi Klasik}

Sebelum dilakukan pengujian regresi berganda, perlu dilakukan suatu pengujian asumsi klasik agar model regresi menjadi suatu model yang lebih representatif. Uji asumsi klasik yang digunakan pada penelitian ini adalah uji normalitas data, uji multikoloniearitas, heteroskedastisitas, dan uji autokorelasi.

\section{F. TEKNIK ANALISIS DATA}

Dalam penelitian ini menggunakan beberapa analisis data yaitu analisis statistik deskriptif yang digunakan untuk menggambarkan keadaan variabel-variabel yang mempengaruhi pertumbuhan laba dan analisis statistik inferensial menggunakan bentuk penelitian analisis jalur (Path Analysis). Analisis jalur (Path Analyze) merupakan perluasan dari analisis regresi linier berganda, atau analisis jalur adalah penggunaan analisis regresi untuk menaksir hubungan kausalitas antar variabel yang telah ditetapkan sebelumnya oleh teori (Ghozali, 2011). Bentuk penelitian analisis jalur merupakan metode analisis data multivariat dengan tujuan mengetahui pengaruh langsung dan tidak langsung maupun variabel total beberapa variabel penyebab (eksogen) terhadap variabel endogen (akibat) dengan pola hubungan antar variabel adalah satu arah dan semua variabel dapat diobservasi langsung. 


\section{G. HASIL PENELITIAN}

Uji Kualitas Data

Uji Normalitas

Tabel 1. Hasil Uji One Sample Kolmogorov Smirnov Test

\begin{tabular}{lccc}
\hline \hline Variabel & Asymp. Sig. (2-tailed) & Nilai Standarisasi & Keterangan \\
\hline DAR & 0.231 & 0.05 & Normal \\
\hline DER & 0.353 & 0.05 & Normal \\
\hline ROA & 0.464 & 0.05 & Normal \\
\hline Pertumbuhan Laba & 0.123 & 0.05 & Normal \\
\hline
\end{tabular}

Sumber : Data primer yang diolah 2019

Pada uji normalitas data menggunakan One Sample Kolmogorov Smirnov Test, dapat disimpulkan bahwa semua variabel memiliki data normal, hal tersebut dikarenakan data tersebut memiliki Asymp. Sig > (a) 0,05.

\section{Uji Multikolinearitas}

Tabel 2. Hasil Uji Tolerance dan VIF

\begin{tabular}{lccc}
\hline \hline \multicolumn{1}{c}{ Variabel bebas } & Tolerance & VIF & Keterangan \\
\hline DAR & 0.105 & 9.486 & Non multikolineritas \\
\hline DER & 0.102 & 9.850 & Non multikolineritas \\
\hline ROA & 0.870 & 1.149 & Non multikolineritas \\
\hline
\end{tabular}

Sumber : Data primer yang diolah 2019

Pada uji multikolinearitas menggunakan nilai tolerance dan VIF diperoleh semua variabel bebas memiliki nilai tolerance masing-masing DAR (0,105), DER $(0,102)$, ROA $(0,870)>0,1$ dan nilai VIF masing- masing DAR $(9,486)$, DER $(9,850)$, ROA $(1,149)<10$. Maka dapat disimpulkan bahwa model regresi terbebas dari masalah multikolinearitas.

\section{Uji Heterokedastisitas}

Tabel 3. Hasil Uji Glejser

\begin{tabular}{lcl}
\hline \hline $\begin{array}{c}\text { Variabel } \\
\text { Independen }\end{array}$ & $\begin{array}{c}\text { Abs_Res } \\
\text { Sig. (2-Tailed) }\end{array}$ & Keterangan \\
\hline DAR & 0.706 & Bebas Heterokedastisitas \\
\hline DER & 0.776 & Bebas Heterokedastisitas \\
\hline ROA & 0.317 & Bebas Heterokedastisitas \\
\hline
\end{tabular}

Sumber : Data primer yang diolah 2019

Dari hasil uji Glejser menunjukkan bahwa masing-masing variabel tersebut tidak memiliki pengaruh secara signifikan sehingga berarti tidak terjadi heteroskedastisitas atau nilai signifikan untuk ketiga variable yaitu DAR $(0,706)$, DER $(0,776)$, dan ROA $(0,317)>0,05$. Karena signifikansi lebih besar daripada 0,05 , maka dapat disimpulkan bahwa tidak terjadi problem heteroskedasitas. 


\section{Uji Autokorelasi}

Tabel 4. Hasil Uji Durbin-Watson

\begin{tabular}{cccccc}
\hline \hline $\mathbf{d}_{\mathbf{l}}$ & $\mathbf{d}_{\mathbf{u}}$ & $\mathbf{4 - \mathbf { d } _ { \mathbf { u } }}$ & $\mathbf{4 - \mathbf { d } _ { \mathbf { l } }}$ & $\mathbf{D W}$ & Kesimpulan \\
\hline 1.659 & 1.757 & 2.243 & 2.341 & 1.913 & Non Autokorelasi \\
\hline
\end{tabular}

Berdasarkan tabel di atas diketahui bahwa nilai durbin watson (DW) adalah 1,913. Pada tabel DW untuk jumlah observasi $(\mathrm{n})=125, \mathrm{~K}^{\prime}=$ 3 dan signifikansi $5 \%$ diperoleh nilai $\mathrm{dL}$ sebesar 1,659 dan du sebesar 1,757. Sehingga pada model persamaan regresi nilai DW berada pada daerah du $<$ d $<4$-du $(1.757<1.913<2.243)$. Maka dapat disimpulkan tidak ada autokorelasi.

\section{Uji Analisis Jalur (Path Analysis)}

Model path analysis digunakan untuk menganalisis hubungan antar variabel dengan tujuan untuk mengetahui pengaruh langsung maupun tidak langsung seperangkat variabel bebas (eksogen) terhadap variabel terikat (endogen).

Berikut hasil analisis jalur antara variabel independen yaitu DAR dan DER dan variabel intervening yaitu ROA serta variabel dependen yaitu Pertumbuhan Laba.

Tabel 5. Hasil Pengujian Path Analysis

\begin{tabular}{lccccc}
\hline \hline Struktural & $\begin{array}{c}\text { Koefisien } \\
\text { Jalur }\end{array}$ & $\mathbf{t}_{\text {hitung }}$ & $\mathbf{t}_{\text {tabel }}$ & $\mathbf{p}$-value & Kesimpulan \\
\hline $\mathrm{X}_{1} \rightarrow \mathrm{Z}$ & 0,319 & 1,236 & 1,979 & 0,219 & Tidak Signifikan \\
$\mathrm{X}_{2} \rightarrow \mathrm{Z}$ & $-0,647$ & $-2,504$ & $-1,979$ & 0,014 & Signifikan \\
$\mathrm{X}_{1} \rightarrow \mathrm{Y}$ & 0,549 & 2,158 & 1,979 & 0,033 & Signifikan \\
$\mathrm{X}_{2} \rightarrow \mathrm{Y}$ & $-0,670$ & $-2,584$ & $-1,979$ & 0,011 & Signifikan \\
$\mathrm{Z} \rightarrow \mathrm{Y}$ & $-0,423$ & $-4,778$ & $-1,979$ & 0,000 & Signifikan \\
\hline
\end{tabular}

Sumber : Data primer yang diolah 2019

Dari tabel di atas dapat diketahui estimasi dari koefisien path analysis, maka dapat dibangun sebuah model structural berdasarkan koefisien path dan juga berdasarkan konstruk model teoritis. Pengaruh DAR dan DER terhadap pertumbuhan laba melalui ROA baik pengaruh langsung, pengaruh tidak langsung dan pengaruh total dapat digambarkan alurnya sebagai berikut: 


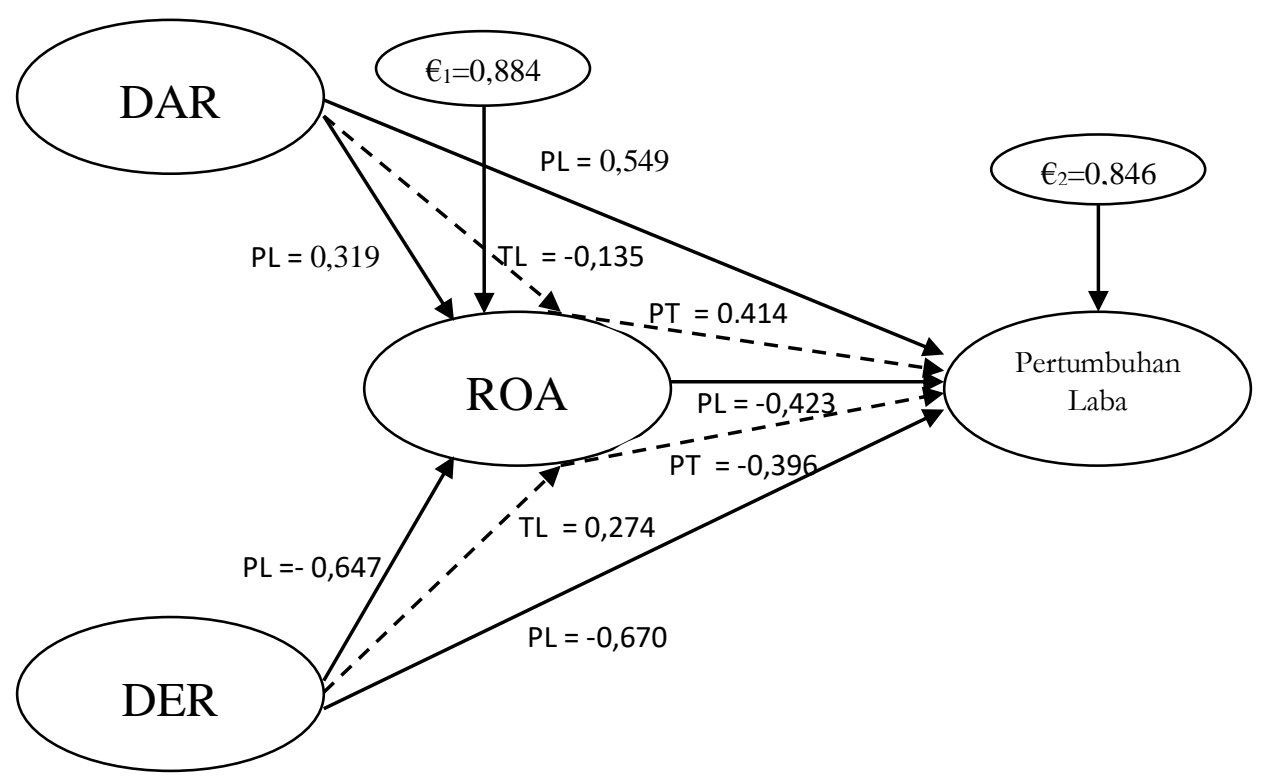

Gambar 2. Pengaruh Langsung dan Tidak Langsung serta Pengaruh Total

\section{H. PEMBAHASAN}

\section{Pengaruh Langsung DAR terhadap ROA}

Dari hasil pengujian menunjukkan bahwa Debt to Asset Ratio (DAR) berpengaruh positif dan tidak signifikan terhadap Return on Assets (ROA) dengan pengaruh langsung sebesar 0,319 . Hal ini disebabkan rata-rata nilai Debt to Asset Ratio (DAR) dari setiap perusahaan LQ-45 di Bursa Efek Indonesia tidak terlalu besar yang mengindikasikan bahwa rasio utang perusahaan LQ-45 adalah kecil. Hal ini mengakibatkan tidak menimbulkan perbedaan nilai Return on Assets (ROA) yang tidak signifikan. Semakin besar Debt to Asset Ratio (DAR) menunjukkan semakin besar tingkat ketergantungan terhadap pihak luar dan berdampak, dimana dengan utang yang semakin banyak akan menyebabkan perusahaan kurang sehat, yang berakibat buruk terhadap perolehan laba. Hal ini pada akhirnya akan menurunkan Return on asset (ROA).

Hasil penelitian ini sesuai dengan penelitian yang dilakukan oleh Zuliana
Zulkarnaen (2018) yang menyatakan bahwa DAR berpengaruh signifikan terhadap ROA, namun penelitian ini tidak didukung penelitian yang dilakukan oleh Azzalia Feronicha Wianta Efendi \& Seto Sulaksono Adi Wibowo (2017) yang menunjunkkan bahwa DAR berpengaruh signifikan terhadap ROA.

\section{Pengaruh Langsung DER terhadap ROA}

Hasil penelitian ini menunjukkan DER berpengaruh negatif terhadap ROA dengan pengaruh langsung sebesar $-0,647$. Hal ini berarti bahwa apabila DER mengalami kenaikan maka akan menurunkan jumlah ROA, sebaliknya apabila DER mengalami penurunan maka akan menaikkan jumlah ROA. Hasil penelitian ini sejalan dengan teori yang menyatakan bahwa hutang mempunyai dampak yang buruk terhadap kinerja perusahaan, karena tingkat hutang yang semakin tinggi berarti akan mengurangi keuntungan. Artinya karena semakin tinggi nilai DER atau hutang yang dimiliki oleh perusahaan, 
maka tingkat untuk memperoleh keuntungan akan semakin rendah.

Hasil penelitian ini juga sejalan dengan penelitian yang dilakukan oleh Azzalia Feronicha Wianta Efendi \& Seto Sulaksono Adi Wibowo (2017), Mahardhika, P.A \& Marbun, D.P (2016), Ni Kadek Venimas Citra Dewi, dkk (2015), Dian Pramesti, dkk (2016) yang menunjunkkan bahwa DER berpengaruh signifikan terhadap ROA.

\section{Pengaruh Langsung DAR terhadap Pertumbuhan Laba}

Berdasarkan hasil pengujian DAR terhadap pertumbuhan laba memperlihatkan DAR mempunyai pengaruh positif dan signifikan terhadap pertumbuhan laba dengan pengaruh langsung sebesar 0,549. Tingginya DAR memperlihatkan kinerja suatu perusahaan tergolong kurang baik sebab nilai utang yang semakin tinggi, sehingga Debt to asset ratio akan berpengaruh signifikan terhadap pertumbuhan laba. Dalam hal ini dapat diindikasikan bahwa semakin besar debt to asset ratio nya maka perusahaan itu akan mengalami penurunan aktiva atau pemasukan yang lebih kecil di perusahaan itu sendiri. Dan sebaliknya apabila semakin kecil debt to asset ratio nya maka perusahaan itu akan mengalami kenaikan aktiva atau pemasukan yang lebih besar. Hasil penilitian ini didukung oleh Danny oktanto dan M.Nuryatno (2014) yang menyatakan bahwa debt to asset ratio berpengaruh signifikan.

Penelitian ini sependapat oleh (Ifada, Luluk Muhimatul \& Tiara Puspitasari, 2016; Wibisono, Septian Adi \& Triyonowati, 2016; Zakaria, Mohamad Rizki. Dkk, 2015; Oktanto, Danny \& Muhammad Nuryatno Amin, 2014; Hermanto, Suwardi B., 2007) hasil pengujian menunjukkan bahwa DAR mempunyai pengaruh signifikan terhadap pertumbuhan laba. Namun penelitian lain menunjukan hasil yang berbeda (Nunki, Kadek \& Sasi Agustin, 2014; Kurniawati, Yesi Astuti \& Triyonowati, 2017). Dengan hasil ini menunjukkan bahwa DAR tidak bepengaruh signifikan.

\section{Pengaruh Langsung DER terhadap Pertumbuhan Laba}

Hasil pengujian statistik t atau uji parsial menunjukkan bahwa terdapat pengaruh negatif dan signifikan debt to equity ratio terhadap pertumbuhan laba perusahaan dengan pengaruh langsung sebesar $-0,670$. Nilai debt to equity ratio yang rendah atau kecil menunjukkan bahwa perusahaan LQ45 lebih banyak modal sendiri dalam membiayai operasional perusahaan dibandingkan dana dari pihak kreditor, maka dari itu resiko kreditur semakin kecil sehingga mengakibatkan semakin kecil tingkat keamanan dana yang ditempatkan oleh kreditur dalam bisnis tersebut. Berpengaruhnya debt to equity ratio terhadap perubahan laba menunjukkan bahwa debt to equity ratio yang tinggi cenderung mengalami peningkatan perubahan laba sedangkan dengan debt to equity ratio yang rendah cenderung mengalami penurunan perubahan laba. Hal ini dikarenakan semakin tinggi debt to equity ratio mengindikasikan bahwa total hutang yang tinggi dimana banyaknya dana kreditor yang masuk sehingga dapat digunakan untuk menghasilkan atau meningkatkan laba. Dana tersebut dapat digunakan dalam membantu proses produksi yang dapat meningkatkan penjualan atau pendapatan perusahaan.

Penelitian ini sependapat dengan (Mahaputra, I Nyoman Kusuma Adnyana, 2012; Hermanto, Suwardi B., 2007; Oktanto, Danny \& Muhammad Nuryatno Amin, 2014; Wibisono, Septian Adi \& Triyonowati, 2016; 
Narpatilova, Oktapiana, 2013) yang menyatakan bahwa proporsi Debt to Equity Ratio (DER) berpengaruh signifikan terhadap Pertumbuhan Laba. Namun penelitian ini tidak sejalan dengan penelitian yang dilakukan oleh (Ifada, Luluk Muhimatul \& Tiara Puspitasari, 2016; Meilyanti, 2017; Lestari, Sri, 2014) hasil pengujian menunjukkan bahwa DER tidak mempunyai pengaruh dengan perubahan laba perusahaan.

\section{Pengaruh Langsung ROA terhadap Pertumbuhan Laba}

Hasil penelitian menunjukkan bahwa secara parsial variabel Return On Asset mempunyai pengaruh negatif dan signifikan terhadap Pertumbuhan Laba dengan pengaruh langsung sebesar -0,423. Return On Asset merupakan ukuran kemampuan perusahaan dalam menghasilkan laba bersih dengan semua aktiva yang dimiliki oleh perusahaan. Hal ini sejalan dengan teori yang menyatakan bahwa semakin tingginya rasio Return On Asset menunjukkan bahwa semakin besar kemampuan perusahaan mengelola aktiva yang dimiliki secara efektif dan efisien, sehingga dapat mendukung pertumbuhan laba. Apabila Return On Asset mengalami peningkatan maka pertumbuhan laba akan mengalami peningkatan, dan sebaliknya. Nilai Return On Asset yang semakin tinggi menunjukkan suatu perusahaan semakin efisien dalam memanfaatkan aktivanya untuk memperoleh laba, hal ini mengindikasikan bahwa perusahaan mampu memanfaatkan total aset yang dimiliki dalam melakukan kegiatan operasionalnya untuk menghasilkan pendapatan, sehingga dengan meningkatnya pendapatan perusahaan pada akhirnya juga akan meningkatkan laba perusahaan. Meningkatnya laba menunjukan tingkat profitabilitas yang tinggi pada perusahaan tersebut, dengan tingkat profitabilitas yang tinggi mencerminkan perusahaan tersebut berjalan dengan baik.

Hasil penelitian ini sejalan dengan (Susanti. Nita Hari \& Siti Rokhmi Fuadati, 2014; Sulistyowati \& Bambang Suryono, 2017; Meilyanti, 2017; Martunis \& Ghazali Syamni, 2013; Prasetyo, Rony Yuda. Dkk, 2016) yang menunjukkan $R O A$ berpengaruh signifikan terhadap perubahan laba perusahaan. Hal ini sejalan dengan teori yang menyatakan bahwa semakin tingginya rasio $R O A$ menunjukkan bahwa semakin besar kemampuan perusahaan mengelola aktiva yang dimiliki secara efektif dan efisien, sehingga dapat mendukung pertumbuhan laba (Meilyanti, 2017). Tetapi penelitian ini tidak konsisten dengan penelitian yang dilakukan oleh (Riana D, Diyani LA, 2016; yang menghasilkan bahwa ROA tidak berpengaruh dalam memprediksi perubahan laba.

\section{Pengaruh DAR dan DER Terhadap Pertumbuhan Laba dimediasi Oleh ROA}

Secara simultan dari variabel $\operatorname{DAR}\left(\mathrm{X}_{1}\right)$, DER $\left(\mathrm{X}_{2}\right)$ dan ROA $(\mathrm{Z})$ menunjukkan bahwa $F_{\text {hitung }}$ sebesar 8,504 dan $F_{\text {tabel }}$ sebesar 2,678 dengan taraf signifikansi $5 \%$ dan memiliki nilai probabilitas 0,000 . Oleh karena $F_{\text {hitung }}$ $>F_{\text {tabel }}$ atau 8,504 > 2,678 dan probabilitas $0,000<0,05$ maka $\mathrm{Ha}$ diterima, sehingga persamaan regrezi $Y$ atas $X 1, X 2$ dan $Z$ berarti secara simultan DAR, DER dan ROA berpengaruh signifikan terhadap pertumbuhan pada perusahaan LQ-45 yang terdaftar di BEl periode 20142017. Besarnya tingkat pengaruh ketiga variabel ini secara bersamasama mengalami kenaikan maka akan berdampak pada kenaikan tingkat pertumbuhan laba, begitu pula sebaliknya. 
Berdasarkan hasil pengujian menunjukkan DAR berpengaruh positif dan tidak signifikan terhadap ROA dan ROA berpengaruh negatif dan signifikan terhadap pertumbuhan laba, dengan koefisien path sebesar -0,135 sehingga diperoleh pengaruh total dari DAR terhadap pertumbuhan laba dan DAR terhadap Pertumbuhan laba melalui ROA sebesar 0,414.

Dari hasil perhitungan di atas ditemukan bahwa pengaruh total DAR melalui ROA terhadap pertumbuhan laba lebih kecil dibanding pengaruh langsung DAR terhadap Pertumbuhan laba sebesar 0,549 $(0,414<0,549)$. Temuan tersebut dapat disimpulkan bahwa ROA bukan merupakan variabel intervening atau mediating dari DAR terhadap pertumbuhan laba pada Perusahaan LQ-45 di BEI. Oleh karena itu, upaya untuk meningkatkan pertumbuhan laba pada Perusahaan LQ-45 sebaiknya langsung meningkatkan DAR.

Hasil pengujian hipotesis DER terhadap pertumbuhan laba melalui ROA menunjukkan bahwa DER berpengaruh negatif dan signifikan terhadap ROA dan ROA berpengaruh negatif dan signifikan terhadap pertumbuhan laba, dengan koefisien path sebesar 0,274 , sehingga diperoleh pengaruh total dari DER terhadap pertumbuhan laba dan DER terhadap pertumbuhan laba melalui ROA sebesar $-0,396$.

Dari hasil perhitungan di atas ditemukan bahwa pengaruh total DER melalui ROA terhadap pertumbuhan laba lebih besar dibanding pengaruh langsung DER terhadap Pertumbuhan laba sebesar $-0,670(-0,396>-0,670)$. Temuan tersebut dapat disimpulkan bahwa ROA merupakan variabel intervening atau mediating dari DER terhadap pertumbuhan laba pada Perusahaan LQ-45 di BEI. Oleh karena itu, upaya untuk meningkatkan pertumbuhan laba pada Perusahaan LQ-45 sebaiknya meningkatkan ROA terlebih dahulu.

\section{SIMPULAN DAN SARAN \\ 1) Simpulan}

Dari hasil penelitian dan pembahasan mengenai pengaruh DER dan DAR terhadap pertumbuhan laba yang dimediasi oleh ROA pada perusahaan LQ-45 yang terdaftar di Bursa Efek Indonesia periode 20142017, maka penulis memperoleh beberapa kesimpulan sebagai berikut:

1. Debt to Assets Ratio secara langsung berpengaruh positif dan tidak signifikan terhadap Return On Assets pada perusahaan LQ45 yang terdaftar di BEl periode 2014 - 2017, dengan koefisien path sebesar 0,319.

2. Debt to Equity Ratio secara langsung berpengaruh negatif dan signifikan terhadap Return On Assets pada perusahaan LQ-45 yang terdaftar di BEI periode 2014 - 2017, dengan koefisien path sebesar $-0,647$.

3. Debt to Assets Ratio secara langsung berpengaruh positif dan signifikan terhadap pertumbuhan laba pada perusahaan LQ-45 yang terdaftar di BEl periode 2014 2017, dengan koefisien path sebesar 0,549.

4. Debt to Equity Ratio secara langsung berpengaruh negatif dan signifikan terhadap pertumbuhan laba pada perusahaan LQ-45 yang terdaftar di BEl periode 2014 2017, dengan koefisien path sebesar $-0,670$.

5. Return On Assets secara langsung berpengaruh negatif dan signifikan terhadap pertumbuhan laba pada perusahaan LQ-45 yang terdaftar di BEl periode 2014 - 2017, dengan koefisien path sebesar 0,423 . 
6. ROA bukan merupakan variabel intervening atau mediating dari DAR terhadap pertumbuhan laba pada Perusahaan LQ-45 yang terdaftar di BEl periode 2014 2017.

7. ROA merupakan variabel intervening atau mediating dari DER terhadap pertumbuhan laba pada Perusahaan LQ-45 yang terdaftar di BEl periode 2014 2017.

8. Secara simultan ROA merupakan variabel intervening atau mediating dari DAR dan DER terhadap pertumbuhan laba pada Perusahaan LQ-45 yang terdaftar di BEI periode $2014-2017$.

\section{2) Saran}

Dari hasil pembahasan dan kesimpulan dapat disarankan sebagai berikut :

1. Perusahaan LQ-45 sebaiknya lebih menekan biaya-biaya operasional perusahaan, hal ini dilakukan agar laba yang diharapkan dapat ditingkatkan dengan demikian tingkat pertumbuhan laba perusahaan dengan sendirinya juga meningkat.

2. Bagi penelitian selanjutnya sebaiknya meningkatkan atau menambah jumlah sampel dengan menambah periode penelitian sehingga diperoleh hasil penelitian yang lebih baik.

\section{DAFTAR PUSTAKA}

Andarini, Diah. 2007. Analisis Pengaruh Faktor Fundamental Dan Resiko Sistematik Terhadap Harga Saham Pada Perusahaan Manufaktur di BEJ. Skripsi S-1. Universitas Gunadarma Jakarta.
Cahyaningrum, Ndaru Hesti dan Mulyo Haryanto. 2011. Analisis Manfaat Rasio Keuangan dalam Memprediksi Pertumbuhan Laba (Studi Kasus : Perusahaan Manufaktur Yang Terdaftar di Bursa Efek Indonesia Periode 2005 - 2010).

Dewi, Ni Kadek Venimas Citra., Kirya, Wayan Cipta, I Ketut. 2015. Pengaruh LDR, LAR, DER dan CR Terhadap ROA. e-Journal Bisma Universitas Pendidikan Ganesha Jurusan Manajemen (Volume 3 Tahun 2015).

Efendi, Azzalia Feronicha Wianta., Wibowo, Seto Sulaksono Adi. 2017. Pengaruh Debt To Equity Ratio (DER) dan Debt To Asset Ratio (DAR) Terhadap Kinerja Perusahaan di Sektor Keuangan Yang Terdaftar di Bursa Efek Indonesia. Journal Of Applied Managerial Accounting Vol. 1, No. 2, 2017, 157-163.

Fahmi, Irham. 2012. Analisis Kinerja Keuangan. Alfabeta : Bandung.

Ghozali, I. 2011. Aplikasi Analisis Multivariate dengan Program SPSS 19. Edisi Kelima. Penerbit Universitas Diponegoro. Semarang

Harahap, Sofyan Syafri. 2011. Analisis Kritis Atas Laporan Keuangan. PT. Raja Grafindo Persada : Jakarta.

Hermanto, Suwardi B. 2007. Pengaruh Sistem Informasi dan Rasio Keuangan terhadap Perubahan Laba, Usahawan, November, No. 11, Th. XXXVI, hal. 31-41.

Ifada, Luluk Muhimatul \& Tiara Puspitasari. 2016. Analisis Pengaruh Rasio Keuangan Terhadap Perubahan Laba. Fakultas Ekonomi, Universitas 
Islam Sultan Agung. Jurnal Akuntansi \& Auditing Volume 13/No. 1 Tahun 2016 : 97-108.

Indriantoro, N. dan Supomo, B. 2013. Metodologi Penelitian Bisnis untuk Akuntansi \& Manajemen. Fakultas Ekonomika dan Bisnis UGM : Yogyakarta.

Kasmir. 2010. Pengantar Manajeman Keuangan. Jakarta: Kencana

Kasmir. 2014. Analisis Laporan Keuangan. PT. Rajagrafindo Perkasa : Jakarta.

Kurniawati, Yesi Astuti \& Triyonowati. 2017. Pengaruh Rasio Keuangan Terhadap Perubahan Laba Pada Perusahaan Cosmetics And Household. Sekolah Tinggi IImu Ekonomi Indonesia (STIESIA) Surabaya. Jurnal IImu dan Riset Manajemen Volume 6, Nomor 3, Maret 2017.

Lestari, Sri. 2014. Analisis Pengaruh Rasio Keuangan dalam Memprediksi Perubahan Laba pada Perusahaan BUMN yang Terdaftar di BEl Periode 20072011. Karya Ilmiah. Surakarta: Universitas Muhammadiyah.

Mahaputra, I Nyoman Kusuma Adnyana. 2012. "Pengaruh Rasio-Rasio Keuangan terhadap Pertumbuhan Laba pada Perusahaan Manufaktur yang Terdaftar di BEl". Jurnal Akuntansi dan Bisnis.Vol. 7, Nomor 2, Juli2012.

Mahardhika, P.A. dan Marbun, D.P. 2016. Pengaruh Current Ratio dan Debt To Equity Ratio Terhadap ROA. Widyakala Vol.3 Maret 2016 pp 23- 8.

Martunis \& Ghazali Syamni. 2013. Pengaruhopm, Roe Danroa Terhadap Perubahan Laba Pada Perusahaan Telekomunikasi di
Bursa Efek Indonesia. Jurnal Kebangsaan, Vol.2 No.4. Juli 2013.

Meilyanti. 2017. Analisis Pengaruh Rasio Keuangan Terhadap Pertumbuhan Laba Pada Sub Sektor Makanan dan Minuman di Bursa Efek Indonesia Periode Tahun 2012-2016. IImu Admistrasi Bisnis, Fakultas IImu Sosial dan IImu Politik, Universitas Mulawarman. eJournal Administrasi Bisnis, 2017, 5 (4): 1000-1013.

Moeljadi. 2008. Manajemen Keuangan: Pendekatan Kuantitatif dan Kuaitatif. Bayumedia : Malang.

Narpatilova, Oktapiana. (2013). Pengaruh Rasio Keuangan Terhadap Pertumbuhan Laba Pada Perusahaan Manufaktur Yang Terdaftar di Bursa Efek Indonesia Periode 2008-2012. Jurnal Ekonomi dan Bisnis, 8. (3), hal. 142-153.

Nunki, Kadek \& Sasi Agustin. 2014. Faktor-Faktor Mempengaruhi Pertumbuhan Laba Pada Perusahaan Otomotif di BEl. Sekolah Tinggi IImu Ekonomi Indonesia (STIESIA) Surabaya. Jurnal IImu dan Riset Manajemen Vol. 3 No. 8 (2014).

Oktanto, Danny dan Muhammad Nuryatno Amin. 2014. "Pengaruh Rasio Keuangan terhadap Perubahan Laba pada Perusahaan Manufaktur yang Terdaftar di BEI Tahun 20082011". Jurnal Bisnis dan Manajemen.Vol. 1, Nomor 1, Februari2014.

Pardede, Ratlan dan Manurung, Renhard. 2014. Analisis Jalur (Path Analysis) Teori dan Aplikasi dalam Riset Bisnis. Rineka Cipta: Jakarta. 
Petronela, Thio. 2004. Pertimbangan Going Concern Perusahaan Dalam Pemberian Opini Audit. Jurnal Balance, 47-55.

Pramesti, Dian., Wijayanti, Anita., Nurlaela, Siti. 2016. Pengaruh Rasio Likuiditas, Leverage, Aktivitas dan Firm Size Terhadap Profitabilitas Perusahaan Sub Sektor Otomotif dan Komponen di Bursa Efek Indonesia. Seminar Nasional IENACO - 2016 ISSN: $2337-4349$.

Prasetyo, Rony Yuda. Darminto \& Nila Firdausi Nuzula. 2016. Pengaruh Profitabilitas Terhadap Pertumbuhan Perusahaan (Studi pada Perusahaan Properti dan Real Estate yang Terdaftar pada Bursa Efek Indonesia Periode 2011-2013). Jurnal Administrasi Bisnis (JAB). Vol. 30 No. 1 Januari 2016.

Prihartanty, Rima. 2011. Analisis Pengaruh Rasio Likuiditas, Rasio Leverage, Rasio Aktivitas, dan Rasio Profitabilitas Terhadap Net Income Growth (Studi Pada Perusahaan Perdagangan Retail Yang Listed di BEI Periode 2005 - 2009). Universitas Diponegoro Semarang.

\section{Raharjaputra, Hendra. 2009. Manajemen Keuangan dan Akuntansi untuk Eksekutif Perusahaan. Salemba Empat : Jakarta.}

Riana D, Diyani LA. 2016. Pengaruh Rasio Keuangan dalam Memprediksi Perubahan Laba pada Industri Farmasi (Studi Kasus pada BEI Tahun 2011 2014). Jurnal Online Insan Akuntan. 1 (1): 16 - 42.

Rusmanto. 2011. Analisis Rasio Aktivitas Terhadap Pertumbuhan
Laba Pada PT Divo Valasindo di Surabaya. Universitas Pembangunan Nasional VETERAN Jawa Timur.

Sartono, Agus. 2010. Manajemen Keuangan Teori dan Aplikasi. Edisi 4. BPFE : Yogjakarta.

Sudana, I Made. 2011. Manajemen Keuangan Perusahaan. Jakarta: Erlangga.

Sulistyowati \& Bambang Suryono. 2017. Analisis TATO, NPM, dan ROA Terhadap Pertumbuhan Laba Pada Perusahaan Food \& Beverage. Sekolah Tinggi IImu Ekonomi Indonesia (STIESIA) Surabaya. Jurnal IImu dan Riset Akuntansi. Volume 6, Nomor 4, April 2017.

Suprihatmi, SW. 2005. Pengaruh rasio Keuangan terhadap kemampuan memprediksi peruba-han laba pada perusahaan Manufaktur yang terdaftar di Bursa Efek Indonesia. Jurnal Ekonomi dan Kewirausahaan, Vol 6. No.1, April.

Susanti. Nita Hari \& Siti Rokhmi Fuadati. 2014. Analisis Rasio Keuangan Untuk Memprediksi Pertumbuhan Laba Perusahaan Otomotif di BEl. Sekolah Tinggi Ilmu Ekonomi Indonesia (STIESIA) Surabaya. Jurnal IImu \& Riset Manajemen Vol. 3 No. 5 (2014).

Taruh, Victorson. 2011. Analisis Rasio Keuangan dalam Memprediksi Pertumbuhan Laba Pada Perusahaan Manufaktur Yang Terdaftar di BEI. Universitas Maritim.

Wibisono, Septian Adi \& Triyonowati. 2016. Pengaruh Kinerja Keuangan Terhadap Pertumbuhan Laba Pada 
Perusahaan Otomotif di BEl. Sekolah Tinggi llmu Ekonomi Indonesia (STIESIA) Surabaya. Jurnal IImu dan Riset Manajemen : Volume 5, Nomor 12, Desember 2016.

Zakaria, Mohamad Rizki. Sahmin Noholo \& La Ode Rasuli. 2015. Pengaruh Debt To Asset Ratio (DAR), Debt To Equity (DER), Dan Times Interest Earned (TIE) Terhadap Pertumbuhan Laba Pada Perusahaan Rokok Yang
Terdaftar di Bursa Efek Indonesia (BEI). Jurusan Akuntansi Universitas Negeri Gorontalo. KIM FE \& Bisnis Vol. 2 No. 3 (2015).

Zulkarnaen, Zuliana. 2018. Pengaruh Debt To Assets Ratio Terhadap Return On Asset Pada Perusahaan Asuransi Yang Terdaftar di BEI Tahun 2010 2015. Jurnal Warta Edisi: 56. April 2018. 